\title{
Eutrophication: A growing problem in the Americas and the Caribbean
}

\author{
E. J. González Rivas ${ }^{a}$ (D), G. Roldán Pérez (D), J. G. Tundisic (D), K. Vammen ${ }^{d}$ (D), \\ B. Örmecie (D) and M. Fordef
}

anstituto de Biología Experimental, Universidad Central de Venezuela, Venezuelan Focal Point of the Inter-American Network of Academies of Sciences - IANAS Water Program, Calle Suapure, Colinas de Bello Monte, 1041, Caracas, Venezuela

${ }^{\mathrm{b}}$ Academia Colombiana de Ciencias Exactas, Físicas y Naturales, Colombian Focal Point of the Inter-American Network of Academies of Sciences - IANAS Water Program, Parcelación Fizebad № 49, El Retiro, Antioquia, Colombia

'Instituto Internacional de Ecología, Brazilian Focal Point of the Inter-American Network of Academies of Sciences IANAS Water Program, R. Bento Carlos, 750 - Centro - 13.560-660, São Carlos, SP, Brasil

${ }^{d}$ Universidad Centroamericana, Institute of Interdisciplinary Research in Natural Sciences, Nicaraguan Focal Point of the IANAS Water Program, Apartado Nº 6117, Managua, Nicaragua

${ }^{\mathrm{e} C}$ Carleton University, Global Water Institute, Canadian Focal Point of the Inter-American Network of Academies of Sciences - IANAS Water Program, 1125 Colonel By Drive, ON K1S 5B6, Ottawa, Canada

fSt. George's University, Caribbean Focal Point of the IANAS Water Program, PO Box 7, Grenada, West Indies

*e-mail: ernesto.gonzalez@ciens.ucv.ve

Received: May 11, 2020 - Accepted: May 12, 2020 - Distributed: August 31, 2020

Eutrophication is one of the most prevalent and widespread environmental problems of inland waters in the world. Eutrophication is a natural process that slowly occurs over extended (i.e., geological) time scales; however, anthropogenic activities in the past century have drastically increased its rate, scope, and impact.

In the Americas and the Caribbean, eutrophication is caused by nonexistent or insufficient wastewater treatment; agricultural expansion and overuse of chemical fertilizers; urbanization of watersheds; intensive husbandry of cattle, pigs, and chicken; increase in aquaculture; construction of reservoirs; destruction of natural ecosystems and deforestation; and accelerated erosion in watersheds. These factors increase the nitrogen and phosphorus loads into lakes and reservoirs, which intensify the biological productivity of the water bodies. As a consequence, undesirable ecological problems arise, including excessive phytoplankton and macrophyte growth, proliferation of algal blooms and toxic phytoplankton, fish mortality due to drastic oxygen depletion, proliferation of habitats for vectors of tropical diseases, water quality deterioration, and an even further loss of biodiversity. Harmful algal blooms, caused by some cyanobacterial species, are particularly important if the affected water bodies are used for drinking water. Removal of algal toxins requires advanced treatment processes, and inadequate treatment poses serious health risks to the public. Also, a positive correlation has been found between eutrophication and virus abundance in some receiving water bodies around the world (Cabral et al., 2017), with a concomitant risk for public health. This is an important fact to be considered in the light of the ongoing COVID-19 pandemic.
In connection with human nutrient enrichment (particularly nitrogen and phosphorus), climatic changes, such as global warming and associated hydrologic changes, also are implicated in eutrophication. Warming of surface water can selectively promote cyanobacterial blooms since their growth rates are optimized at relatively high temperatures. Since warming of surface water intensifies vertical stratification in freshwaters and increases the period of stratification, the growth of cyanobacteria and duration of blooms is enhanced. Duration of precipitation and droughts are related to cyanobacteria dominance. Therefore the evidences from different aquatic ecosystems indicate that global warming and climatic changes act coupled with nutrient enrichment causing eutrophication. The rapid expansion of blooms such as Cylindrospermopsis raciborskii worldwide in lakes and reservoirs of northern and southern hemispheres is one of the consequences of this synergic process (Kratina et al., 2012; Paerl and Paul, 2012).

The Inter-American Network of Academies of Sciences (IANAS) - Water Program which brings together leading water scientists from 21 National Academies of Sciences of the continent sees the need to alert regional governments, institutions that manage water resources, and the public about the environmental and health problems that arise from eutrophication. More than $40 \%$ of the lakes and reservoirs in the region, both in developing and developed countries, are adversely affected by this phenomenon. Several examples and case studies are demonstrated in the latest book published by the IANAS Water Program titled "Water Quality in the Americas" which can be downloaded for free (IANAS, 2019). 
The IANAS Water Program recommends that high-level multidisciplinary teams be formed, where scientists, politicians, water quality managers, policymakers, and communities discuss and agree on the necessary measures to mitigate and reverse the adverse effects of eutrophication and prevent future increases in the number of eutrophic aquatic ecosystems.

Eutrophication has severe economic consequences in countries, regions, and towns. Loss of ecosystem services of rivers, reservoirs and natural lakes, impaired water quality with damage to fisheries, tourism, recreation and aquatic sports, real estate, and effects on human health has a major cost, and in the U.S. alone is estimated to be US\$ 2.2 billion annually. Eutrophication is an existential threat to sustainable development and must be addressed for the protection and recovery of the freshwater resources in the Americas and the Caribbean, in order to ensure that the region's vital resources are preserved for the benefit of all.

\section{References}

CABRAL, A.S., LESSA, M.M., JUNGER, P.C., THOMPSON, F.L. and PARANHOS, R., 2017. Virioplankton dynamics are related to eutrophication levels in a tropical urbanized bay. PLoS One, vol. 12, no. 3, pp. 1-16. http://dx.doi.org/10.1371/journal. pone.0174653. PMid:28362842.

INTER-AMERICAN NETWORK OF ACADEMIES OF SCIENCES - IANAS, 2019 [viewed 10 January 2020]. Water quality in the Americas. Risks and opportunities [Online]. México: IANAS. Available from: https://www.ianas.org/images/books/wb10d.pdf.

KRATINA, P., GREIG, H.S., THOMPSON, P.L., CARVALHOPEREIRA, T.S. and SHURIN, J.B., 2012. Warming modifies trophic cascades and eutrophication in experimental freshwater communities. Ecology, vol. 93, no. 6, pp. 1421-1430. http://dx.doi. org/10.1890/11-1595.1. PMid:22834382.

PAERL, H.W. and PAUL, J.V., 2012. Climate change: Links to global expansion of harmful cyanobacteria. Water Research, vol. 46, no. 5, pp. 1349-1363. http://dx.doi.org/10.1016/j. watres.2011.08.002. PMid:21893330. 